\title{
Nurse's means of work in the articulation of the psychosocial care network
}

\author{
Meios de trabalho do enfermeiro na articulação da rede de atenção psicossocial \\ Medios de trabajo del enfermero en la articulación de la red de atención psicosocial
}

\author{
Fabrício Soares Braga ${ }^{a}$ \\ Agnes Olschowskyb \\ Christine Wetzel $^{\mathrm{b}}$ \\ Aline Basso da Silva ${ }^{b}$ \\ Cristiane Kenes Nunes ${ }^{a}$ \\ Mariane da Silva Xavier Botega ${ }^{a}$
}

\begin{abstract}
How to cite this article: Braga FS, Olschowsky A, Wetzel C, Silva AB, Nunes CK, Botega MSX.Nurse's means of work in the articulation of the psychosocial care network. Rev Gaúcha Enferm. 2020;41(esp):e20190160 doi: https://doi.org/10.1590/19831447.2020.20190160
\end{abstract}

Universidade Federal do Rio Grande do Sul (UFRGS) Escola de Enfermagem, Programa de Pós-Graduação em Enfermagem. Porto Alegre, Rio Grande do Sul, Brasil

Universidade Federal do Rio Grande do Sul (UFRGS), Escola de Enfermagem, Departamento de Assistência e Orientação Profissional. Porto Alegre, Rio Grande do Sul, Brasil

\section{ABSTRACT}

Objective: To analyze nurses' means of work used in the articulation of the Psychosocial Care Network (PCN)

Method: An exploratory-descriptive qualitative study conducted at the PCN of a District Health Management in Porto Alegre. The data collection technique used was the semi-structured interview held from October to December 2017. Data was subjected to thematic analysis under the Marxist theory of the Labor Process.

Results: The analysis resulted in two thematic categories: Care Management and Care Practices. The first consists of two means of work: team coordination and meetings with the other components of the territory. The second involves three means of work: telephone contacts with PCN services; user referrals in the PCN and matrix support.

Final considerations: In view of overcoming the asylum model, nurses'means of work are instruments for producing dialogs aimed at expanding psychosocial care.

Keywords: Nurses. Work. Nursing care. Mental health. Community networks.

\section{RESUMO}

Objetivo: Analisar os meios de trabalho do enfermeiro utilizados na articulação da Rede de Atenção Psicossocial (RAPS).

Método: Estudo qualitativo exploratório-descritivo, realizado na RAPS de uma Gerência Distrital de saúde de Porto Alegre. Utilizou-se como técnica de coleta de dados a entrevista semiestruturada, realizada no período de outubro a dezembro de 2017. Os dados foram submetidos à análise temática sob referencial marxista do Processo de Trabalho.

Resultados: A análise resultou em duas categorias temáticas: Gestão do Cuidado e Práticas de Cuidado. A primeira é composta por dois meios de trabalho: coordenação de equipe e reuniões com os demais componentes do território. A segunda envolve três meios de trabalho: contatos telefônicos com serviços da RAPS; encaminhamentos do usuário na RAPS e apoio matricial.

Considerações finais: Tendo em vista a superação do modelo manicomial, os meios de trabalho dos enfermeiros são instrumentos de produção de diálogos que visam ampliar o cuidado psicossocial.

Palavras-chave: Enfermeiras e enfermeiros. Trabalho. Cuidados de enfermagem. Saúde mental. Redes comunitárias.

\section{RESUMEN}

Objetivo: Analizar los medios de trabajo utilizados por los enfermeros en la articulación de la Red de Atención Psicosocial (RAPS).

Método: Estudio cualitativo, exploratorio y descriptivo realizado en la RAPS de un Distrito de Gestión de la Salud en Porto Alegre. La técnica de recolección de datos utilizada fue la entrevista semiestructurada, de octubre a diciembre de 2017. Los datos se sometieron al análisis temático bajo la teoría marxista del proceso de trabajo.

Resultados: El análisis derivó en dos categorías temáticas: gestión de la atención y prácticas de atención. El primero consiste en dos medios de trabajo: coordinación del equipo de trabajo y reuniones con los otros componentes del territorio. El segundo implica tres medios de trabajo: contactos telefónicos con servicios de la R APS; referencias de usuarios en la RAPS y soporte de matriz.

Consideraciones finales: En vista de superar el modelo de los manicomios, los medios de trabajo de los enfermeros son instrumentos para producir diálogos destinados a expandir la atención psicosocial.

Palabras clave: Enfermeras y enfermeros. Trabajo. Atención de enfermería. Salud mental. Redes comunitarias. 


\section{口INTRODUCTION}

Mental health care is based on the existence of two models in permanent tension: the asylum mode and the psychosocial mode. The asylum mode focuses on the disease, disregarding the subjectivities of the individuals, as well as it goes against the idea of human rights, since it is based on a treatment focused on punitive and isolation actions. In contrast, the psychosocial mode, arising from the Psychiatric Reform in the 1980s, understands that mental health issues should take into account the existence of multiple factors and situations in human suffering, placing the disease between parenthesis and, valuing cultures, affections, social and economic issues, i.e., biopsychosocial(1).

In line with the psychosocial mode, mental health work should be thought of with society in the territorial context, seeking decent care and addressing human rights violations ${ }^{(1)}$. In this sense, there is also a direction for the individual, perceived as a free citizen, to actively participate in their care when seeking mental health services.

Thus, the care practices that have the purpose of healing, with means of work anchored in psychiatry, are questioned because the cure-solution becomes simplistic, and it is necessary to understand that caring means taking care of changing the ways of living and feeling the suffering ${ }^{(1)}$.

By means of work it is understood the elements that pre-exist in nature without human intervention or previously developed instruments that serve to direct the worker's activity in the transformation of the work object into a intended product(2).

In the nursing care practices, what is questioned is not the care that is produced, but the way it is produced, i.e., with what means of work. Faced with this, the nurse must, in his work process, provide listening and appreciation of the individual in mental distress.

It is understood that the work of nursing is collective, because their actions are performed from the inter-professional and collaborative practice, among workers from different areas, in the sense of integration, teamwork and co-responsibility of patient care ${ }^{(3)}$. On the other hand, it is observed that this integration in the realization of the work in health is still incipient and the nursing work still carries division characteristics within its own professional scope, being composed of different training categories: nurses, technicians and assistants. Each of these workers provides part of the health care separately from the others, performing delegated activities, thus maintaining a limited space for decision making, creation and mastery of knowledge( ${ }^{(4)}$.

It is considered, therefore, that nursing can enhance its work if it performs its practice of team care, in a shared way, breaking with the fragmented logic and focused on the division of labor that occurs in the services that are persistently marked hegemonically with the practices of the asylum mode. Thus, the user will not need to adapt their health needs to the discipline in which each worker has competence and can address the issues that involve the demands of their lives.

In the field of mental health, nurses are challenged to work in a service network that substitutes the asylum mode called the Psychosocial Care Network (RAPS). The RAPS is comprised of different primary, secondary and tertiary health care services that should promote health to care for individuals with mental conditions and with demands related to the use of crack, alcohol and other drugs ${ }^{(5-6)}$.

For the health services to function as a network, it is necessary to change the logic of work and the relationship among the services, so that they seek to strengthen communication and linking with each other, working horizontally and in an integrated manner, exchanging information and responsibilities. In order for this to happen, the actions taken at the RAPS' points of attention must be connected. That is, they must be articulated in a way that puts the network and users in motion ${ }^{(7)}$.

Thus, this paper has the following as its guiding question: which means of work are used by the nurses and how do they influence the articulation of the Psychosocial Care Network? Therefore, the objective was to analyze the means of work of nurses used in the articulation of the Psychosocial Care Network. The choice of the theme is justified by the need to deepen the study of the organization of the nursing work in mental health, in a context of paradigmatic transformation, as a result of the psychiatric reform, in constant tension. Because it is understood that, reflecting the changes, the potentialities and the difficulties in the work process of nursing in mental health, it is possible to expand approaches, strategies and means of work that value the collectivity, humanized psychosocial attention and respect for the rights of users of mental health services.

\section{METHOD}

An exploratory-descriptive study with a qualitative approach, which allows obtaining information by approaching the researcher of phenomena and experiences by the individuals themselves ${ }^{(8)}$, derived from the master's dissertation entitled "The work of nurses in the construction of the Psychosocial Care Network"(9).

The services of the Unified Health System (Sistema Único de Saúde, SUS) of Porto Alegre are distributed in 17 Health Districts (HDs), which form the eight District Managements 
(DMs). DMs are regional administrative and management structures. They are characterized as spaces for discussion and practice where the strategies for health care in the SUS are formulated. Thus, this study was conducted together with the RAPS, in different HDs linked to a DM of Porto Alegre, in the services that had nurses in the team. The participants were chosen intentionally, by invitation, and according to the inclusion criteria of working at least three months in the DM's RAPS services, excluding workers who were away from work for vacation or leave. Thus, 12 nurses participated in the study. In order to preserve the anonymity of the participants, in their speeches their names were replaced by the letter $\mathrm{E}$ ("Enfermeiros" in Portuguese, nurses), followed by an ordinal number from 1 to 12 (E1 to E12).

The information was collected through semi-structured interviews, from October to December 2017. This instrument combined closed and open questions in which the interviewee had the possibility to talk about the theme without being attached to the question formulated, obeying a script that is physically appropriate and used by the researcher ${ }^{(8)}$. The script had two guiding questions: talk about the work you do involving the other mental health services in the network; and what benefits can this work bring to the network?

For data systematization, the analysis of information content through thematic analysis was used ${ }^{(8)}$ under the Marxist framework of the Labor Process which breaks down this process into three moments: the goal-oriented activity (the work itself), the work object (an element that will be modified through work and transformed into a product) and the means of work (instrument that the worker uses in the object of work as a guide for the activity) $)^{(2)}$. The thematic analysis was performed in three stages: pre-analysis; exploration of the material; and data processing, inference and interpretation ${ }^{(8)}$. In the pre-analysis stage, the reading and checking of the textual transcription of the audio of each interview was implemented, inserted in the Nvivo 11 software, selecting the record units and the context units. In the exploration of the material, the categorization aggregated each context unit into understanding cores to conform the thematic categories. In the treatment of the obtained results and interpretation, this information was analyzed in the light of the theoretical framework.

The participants signed the Free and Informed Consent Form (FICF), following National Health Council Resolution $466 / 12$ for the ethical considerations. This study is approved by the Research Ethics Committee of the Porto Alegre Municipal Secretariat under CAAE No. 72361717030015338 , of October 2017.

\section{RESULTS AND DISCUSSION}

Twelve nurses participated, eight from Primary Health Care Units, one from the Adult Mental Health Team (Equipe de Saúde Mental Adulto, ESMA), one from the Psychosocial Care Center II (Centro de Atenção Psicossocial II, CAPS II), one from the Psychosocial Care Center for Alcohol and Drugs (Centro de Atenção Psicossocial Álcool e Drogas, CAPSad) and one from the Emergency Care Unit (Unidade de Pronto Atendimento, UPA). Among these, the time since graduation as a nurse ranged from 5 to 34 years of education with a mean of 14.1 years. Regarding the time working in their respective services, it extended from 1 to 7 years. These times demonstrate the heterogeneity of the set of participants as workers of health care.

The conception of work on which the study is based is in agreement with the Marxist theory of intentionality of human labor activity defended by Marx in Capital, that is, "at the end of the labor process, one gets a result that was already present in the representation of the worker at the beginning of the process, therefore, a result that already existed ideally"(2).

In the analysis of the information of this study, we identified five ways of work of nurses that make up the two thematic categories: Care Management and Care Practices. The first is related to activities directed to the workers, the environment and the health unit, and consists of two means of work: team coordination and meetings with the other components of the territory. The second is the performance of nursing care actions and involves three means of work: telephone contacts with the RAPS' services; user forwarding in the RAPS and matrix support.

The nurses are directly involved in management actions focused on service users, i.e., management actions linked to care activities ${ }^{(10)}$. Thus, these two unified thematic categories characterize the work process of nurses.

Care Management is a nurse's assignment directly related to the pursuit of quality care, being a means of work for the implementation of the health policies, better working conditions and a facilitator in the interpersonal relationship process of the team, establishing links and organization to achieve comprehensive care ${ }^{(11)}$. In this way, we present team coordination as a means of work in this category.

For five years I've been here at the City Hall as a Coordinator of CAPS II. [...] Currently, I manage the CAPS, all the Human Resources parts, of time clock, of going to meetings, representations (E2). 
In addition to assistance, I perform coordination. [...] / have a more administrative shift, to be able to answer e-mails and various other demands that come to this coordination matter (E7).

This work environment, used as a reference for the RAPS articulation, is used by nine nurses from the 12 interviewees. The nurses affirm the need and desire to be together with the users producing care strategies in psychosocial care, even having difficulties in using the team coordination work.

There are some coordinators who prefer to be only in management, but I like the contact with the patient (E3).

In the units we are drowned in this spontaneous demand to serve patients, so many patients that we fail to schedule coordination actions (E4).

It is very difficult to exercise assistance and coordination. Very complicated when you are the only nurse. So, this is the part that I find the hardest. The bureaucratic part takes us a long time (E12).

The testimonies of the interviewees indicate the difficulty of the nurses in performing their activities of direct care (assistance) and indirect (coordination) to the users of the service network, often focusing on the bureaucracies of their positions.

When bureaucratized, the managerial dimension, reduces the nursing work process and makes it mechanistic. From this point of view, despite the fact that the health services are still centered on prescriptive, bureaucratic and technical actions, bureaucracy should not undermine care management, but allow the care manager nurse to understand that he/she is an actor and driver of change and that, through collectively developed planned management actions, can produce care according to the reality of each service scenario ${ }^{(12)}$.

By using team coordination as a means of work, the nurse produces indirect care through the managerial dimension, with an important potential for the articulation of the RAPS, as this becomes the reference for the other components of the territory and can provide good quality care to the user who seeks these services. Thus, care management is qualified in the health services network, promotes a mental health care that meets the user's needs and strengthens the psychosocial aspects.

The meetings with other components of the territory, as a means of care management, are used by the nurses in a collective work to improve communication among the workers, producing health care in a dynamic work process, not alienated, participatory and in accordance with the needs of the users. Regarding this means of work, nurses report:

Next local council meeting, we'll put that up. We want to start [a group] with the elderly (E5).

Collegiate meeting is something that we participate in management. It is a great expanded meeting that is along with the services [primary care], but it's more of a forum that management coordinates, our stuff. All unit coordinators in the region participate (E2).

Specialized mental health services participate [in the RAPS meeting]. Now some things have progressed, there's Hospital E., there's a social worker who participates. Which is pretty cool to organize a user's health. When it has discharge, it often directs to the CAPS. The FASC [Foundation for Social Assistance and Citizenship] had a few moments away, now it is resuming [...] has the participation of mental health policy staff as well. Always have the participation of politics at the monthly meetings. (E3).

The Family Assistance Service [social welfare] helps a lot. And usually the girls, they are very receptive, they come to the team meeting, we discuss some cases too (E8).

The meetings with the other components of the RAPS are a strategic means of articulation and approach of the workers in powerful management spaces and integral care for the users. The nurses reported attending the local council meeting; service team meeting; DM health services coordinators meeting (collegiate meeting); and the DM specialist psychosocial care workers meeting (RAPS meeting).

It is observed in the literature that the greater the multiplicity of individuals and services involved, and the more complex the intervention to solve a given problem, the greater the level of coordination involved achieving the expected result. In situations involving chronicity and its complexities, the simultaneous use of a variety of services and actions is required. Management cannot be seen as static, but dynamic and adjusted to each specificity, seeking to build networks that cooperate, interact and integrate different actors and services involved ${ }^{(13)}$.

The direction of the meeting agenda, in an attempt to remove bureaucratization, allows deliberations of intervention possibilities that will be carried out with the users. Thus, in addition to a bureaucratic meeting, the meetings should have the purpose of bringing workers closer to the discussion of specific users' cases, managing the articulation of the network, meeting the needs of direct and indirect care. It also produces the interrelationship of the workers when 
they know each other personally, seeking the efficiency of the care provided and the commitment of the team to consider the subjectivities of the users.

Dialog in meetings is a power device for network articulation, since this means of work enables the workers to exchange reflections that provide better management of care processes.

The meetings bring the idea of a group dynamism, because it is in this meeting space that a set of participants intertwined by a common goal is united, in which each worker with their differences, experiences and individual singularities, enables an approach to problems, recognition of conflicts to then identify potential or creative resources to propose alternatives and overcome obstacles ${ }^{(14)}$.

The meetings serve as a space for conception and learning of this group, providing a space for debate among its members. Thus, when meeting periodically to discuss work activities, network workers get to know each other and relate through communication, seeking the accomplishment of a task: care.

In the Care Practices category it is observed that telephone contacts with the RAPS' services are means of working that facilitate and speed up communication among the services, positively influencing the organization and strengthening of the network.

In the reports it is possible to analyze that, due to the specificities of each network component, the communication among the services made by telephone calls has different intentions. The nurses of the UPA, for example, mostly use phone calls as a means of work to transfer the users. Thus, the telephone contact is made only with the family members and workers of the bed center and of the SAMU.

It is the nurse who has to keep calling: calls the ambulance to schedule removal; calls the relative, asks this, asks that, asks for the documents. So, the nurse already has assistance and still has all the shifts, the [call from the] central of openings [...] Then takes this information and discusses it with the team (E1).

Reciprocity also happens, the nurses from other RAPS services only contact the UPA in specific cases when trying to get a user hospitalized.

From here to there [UPA], we also call. But this is no guarantee of hospitalization. When do we call? When we call in need of hospitalization (E10).
It is noted that communication is a technology that is present in the use of various means of the nursing work process. The strengthening of relationships with other points of care network, the establishment of direction and management in communication tools enables the health worker to follow the user's path during their flow in the care line. By line of care, it is understood to be the user's path through all the network services that articulate, communicate and use health technologies to solve their demands. It is important to point out that co-responsibility of the workers in this process is necessary, so that the user does not lose his bond with territorial reference services (primary care) ${ }^{(15)}$.

Telephone contacts occur more effectively between primary care and specialized psychosocial health services, facilitating the construction of work processes and care for users. This is because these services meet periodically through collegiate meetings, in which the workers feel empowered to build the network and feel easier to make the connections because of the relationships established in person.

[...] knowing with whom I'm talking to [on the phone] is much easier. We can get around the network better when we know each other (E2).

For the CAPS ad we have the freedom to call direct and make a welcome for this patient there (E7).

Phone contacts are a form of faster communication between nurses from different points of care to give and receive guidance on care to a specific mental health patient.

We exchange many things, call to talk about that patient who is waiting and is not well. So, they know we support them. Somehow, I think we were able to organize a network. [E3]

Telephone contacts also serve as a means of work to combine referrals of mental health users to the network's specialized psychosocial care services.

If the pregnant woman has an individual problem, personal, hand it to me, I make a call. I already call the mental health directly, I try to organize, she leaves with referral to a medical appointment. We already do it that way, for example, pregnant women are a priority. [E9]

The referral of users in the RAPS, as a means of the care practice category, is used in the network articulation among 
the health services that provide open doors (UPA, CAPSad, UBS and ESF). About this, the nurses mention the following:

In cases of alcohol or drug use, we get direct referral in the CAPS ad (E6).

We guide the place and they go, open doors, thus, free demand. They get there, but we don't get any response from the CAPS ad (E8).

To the basic unit, we sometimes forward with own referral document forwarding. But when the patient does not use any medication, we usually only advise that there is a basic unit near his home that he can go (E10).

User referral to other RAPS services is a means of work to initiate the articulation process in order to solve a user's problem. Thus, the referral occurs through a nurse's orientation to meet their demands, seeking to promote the continuity of care to the user produced by health teams. It is considered as a factor that strengthens the RAPS, because it is through it that the user initiates his care line.

The line of care follows an idea of health work that must start from the individual, which is both a body individual and extends to the apprentice, citizen, social and cultural individual. Thus, care actions should start from each identified reality, life and health situation, incorporating the need for new services and actors to compose and work with the complexity of this active and dynamic individual(16). In this sense, the referral can help this individual to have their health situations resolved, taking a walk through the network, incorporating new services, actors and care practices according to their needs.

In the reports, it is observed that the opening of extended night hours has expanded access to primary care and has led nurses to refer users to this unit when the demand for mental health is not an emergency, but needs to be cared for. Thus, by making the referral, the nurse contributes to the reduction of repressed demand.

What we can solve, we solve, otherwise we send them somewhere else. [...] And with the units that are having extended shifts now, such as the Model [Health Center], for example, we can refer some patients there too (E11).

However, it is important to stress that these referrals to other RAPS services, in addition to the need to offer a more dynamic and resolute service, the logic of the transfer of responsibility must be taken into account, which provides the strengthening of unnecessary referrals since, when the user is referred so the other can receive/resolve, without the concern of monitoring and of continuity of care, the possibility of resolution reduces, also causing fragmentation of work and accountability for cases and users.

Regarding the expansion of access promoted by the opening of units at extended hours, it may lose its potentiality if other devices are not simultaneously deployed, such as changes in the scheduling model to prioritize spontaneous demand, models that encourage continued care and prevent spread fragmentation of care in different services in which users are not linked.

This is observed in the literature, which addresses the opening of health care, based on curative molds, prevents co-responsibility and the sharing of care, since health workers are used to send the user for a medical consultation with the specialist based on the conception of signs and symptoms that are presented ${ }^{(17)}$.

The third means of work in the Care Practices theme category is the matrix support performed through cross-consultation, as reported by the nurses:

There are some units that are our references, so they come here on Tuesday to do the matrixes, and often weleave with something to do inside the units (E2).

So, we al ways have these two matrixes. I am a nurse responsible to register using a matrix-based strategy all the children in the EESCA and NurseX is responsible for registering all the adults in theESMA (E7).

The flow changed, before we took it straight to the EESCA, now we do the registration with the NASF and the NASF evaluates. In some cases, they support us, help us and call the family to talk (E8).

Matrix support concerns the shared responsibility for care and the joint construction of interventions, knowledge and practices at different levels of care. This organizational arrangement proposal allows the articulation among the services, and communication among the different workers mediated by inter- and/or trans-disciplinary principles ${ }^{(18)}$.

Cross-consultation, as a tool of matrix support aims at the assistance and pedagogical action among health services, teams of workers and users. This means of work has surpassed its initial sense of consulting, as it comprises an expanded action that covers both user assistance and the team and institution. When developed in a multidisciplinary context, it allows complex cases to be discussed more fully, 
as it involves joint intervention and several workers, as well as allowing a broader view of assisted cases and greater assistance by health teams ${ }^{(19)}$.

In the speeches of the workers, it is observed that the support provided strengthens collective work and greater security in the theme of mental health; however, it faces its resistance to the difficulty of broadened understanding of mental health and participation of all team members.

When we started proposing that we would discuss the cases, see what it was, be discussing with the team, there was a lot of resistance. So, the doctors refused to participate in the matrix support, it happened many times, and it is still focused on the nurse. [...] Those involved in the matrix support are individuals who have somehow more differentiated listening in mental health. So, there are professionals who hate it, who do not like this mental health thing, but these are not the professionals we enroll in the matrix support (E3).

The cases that we cannot handle here in the unit, we take to the matrix support in the CAPS [...]. Usually, this discussion was made by the doctor, but at the moment, we are without a doctor. There other times that we didn't have one. I can usually agree with them and take the cases (E11).

Matrix support through cross-consultation effectively requires the collective participation of the various RAPS workers present. The organization and selection of mental health cases to be registered in the matrix support is responsibility of the primary care nurse and of the doctor, who share this activity to organize the team's work process. Mental health case discussions through cross-consultations are most effective when conducted with interdisciplinary assessments, as it is possible to expand the plurality of health experiences and concepts, and to identify the network resources and the needs and possibilities in building the articulation.

The radicality of the matrix support has promoted a resistance trench for workers to strengthen new ways of building health networks, in contrast to the hegemony of undemocratic coordination and the biomedical model, producing the integration and sharing of care among the network health teams ${ }^{(20)}$.

The meeting of workers gives visibility to the need for these joint actions and, furthermore, the reflection to face the scrapping of specialized services that work with closed doors and the scheduled reception, which can sometimes be considered a reduction of the tool to make it difficult for users to refer these services.
The means of work identified in the nurses' work process (team coordination, meetings with other components of the territory, telephone contacts with the RAPS' services, user referrals in the RAPS and matrix support), in part, still reproduce the thought of seeking specialized services that do not place them as co-responsible for the care of the mental health user in their territory, turning to them (specialized services) to discuss cases and interventions, corroborating the disarticulation in the RAPS and maintaining asylum care focused on the disease.

In contrast, there are potentialities in the means of work used by the nurses that indicate a movement to attempt network communications and territorial care, seeking to effect collective work, contrasting the biomedical model for the construction and strengthening of the RAPS. This movement occurs through the use of relational technologies such as dialog, support among workers, the attempt to broaden the mental health debate in the network.

\section{口FINAL CONSIDERATIONS}

This research analyzed the nurses' means of work used in the articulation of the Psychosocial Care Network: team coordination, meetings with the other components of the territory, telephone contacts with the RAPS' services; user referrals in the RAPS and matrix support.

It is reflected that there is a search for a change of model, felt in the practical need of nurses, from an asylum focus, centered on the disease and social exclusion, to a psychosocial mode, which proposes care in freedom and organized in a network. However, even though there is this movement of change and potential for the articulation of the RAPS, nurses face difficulties in a work that generates shared co-responsibility among the entire network by the process of user care and their return to the territory, as well as approaches beyond illness and specialties.

It is important to highlight that the current political context indicates paths for scrapping and setbacks in the individual-focused psychosocial care mode and its complexities, contributing to the persistence of the traditional model of psychiatry based on actions restricted to medicalization, diagnosis, signs and symptoms. Given this, it is concluded that both nurses and teams, despite the limitations, create possibilities and means of work in the management and practice of care that are potent to strengthen the psychosocial approach in the life of the user, even amidst ministerial norms and ordinances that have been deconstructing 
public inclusion policies and reinforcing the psychiatric counter-reform model.

As a differential, the research brought the listening of nurses about their work environments in various points of the network, aiming at inter-sectoriality and different contexts in mental health care. As a limitation of this study, the fact is pointed out that it was local, i.e., focused on an interest group, and thus presents data from one point of view. It is suggested to conduct qualitative studies that make it possible to hear users and family members about the nursing work in the psychosocial care network.

The implications for nursing and new research on this theme must take into account the permanent need for discussion of health models to strengthen the psychosocial mode, understanding that we still present a care in permanent tension, i.e., with traditional approaches that reinforce the solution of biological problems to the detriment of a biopsychosocial and inter-sectoral network health vision. To this end, the qualitative research can be an important tool for listening to voices that denounce contradictions and dissonances in the daily lives of networks and services.

\section{口EFERENCES}

1. Amarante $P$, Nunes MO. Psychiatric reform in the SUS and the struggle for a society without asylums. Ciênc Saúde Coletiva. 2018;23(6):2067-74. doi: https://doi.org/10.1590/1413-81232018236.07082018

2. Marx K. 0 capital: crítica da economia política - Livro 1. 2a ed. São Paulo: Boitempo; 2017.

3. Souza GC, Peduzzi M, Silva JAM, Carvalho BG. Teamwork in nursing: restricted to nursing professionals or an interprofessional collaboration. Rev Esc Enferm USP. 2016;50(4):640-7. doi: https://doi.org/10.1590/50080623420160000500015

4. Tavares e Souza MM, Pereira JP, Melo CMT. Suffering and precariousness at work in nursing. J Res Fundam Care Online. 2015;7(1):2072-82. doi: https://doi. org/10.9789/2175-5361.2015.v7i1.2072-2082

5. Ministeŕrio da Saúde (BR). Portaria № 3.088, de 23 de dezembro de 2011: Institui a Rede de Atenção Psicossocial para pessoas com sofrimento ou transtorno mental e com necessidades decorrentes do uso de crack, álcool e outras drogas, no âmbito do Sistema Único de Saúde (SUS). Diário Oficial da União [da] República Federativa do Brasil. 2013 mai 21;151 (96 Seção 1):37-8.

6. Ministerio da Saúde (BR). Portaria № 3.588, de 21 de dezembro de 2017: Altera as Portarias de Consolidação no 3 e n 6 , de 28 de setembro de 2017, para dispor sobre a Rede de Atenção Psicossocial, e dá outras providências. Diário Oficial da União [da] República Federativa do Brasil. 2018 jan 22;156(15 Seção 1):46.

\section{- Corresponding author:}

Fabrício Soares Braga

E-mail: fabricio.braga@ufrgs.br
7. Zanardo GLP, Bianchessi DLC, Rocha KB. Dispositivos e conexões da rede de atenção psicossocial (RAPS) de Porto Alegre - RS. Est Inter Psicol. 2018;9(3):80-101.

8. Minayo MCS. 0 desafio do conhecimento: pesquisa qualitativa em saúde. $14^{\mathrm{a}}$ ed. São Paulo: Hucitec; 2014.

9. Braga, FS. 0 trabalho do enfermeiro na construção da Rede de Atenção Psicossocial [dissertação] Porto Alegre (RS): Universidade Federal do Rio Grande do Sul; 2018

10. Gehlen GC, Silva Lima MAD. Nursing work in care practice at Emergency Care Units. Invest Educ Enferm. 2013;31(1):26-35.

11. Treviso P, Peres SC, Silva AD, Santos AA. Competências do enfermeiro na gestão do cuidado. Rev Adm Saúde. 2017;17(69). doi: https://doi.org/10.23973/ras.69.59

12. Soder R, Oliveira IC, Silva LAA, Santos ILG, Peiter CC, Erdmann AL. Desafios da gestão do cuidado na Atenção Básica: perspectiva da equipe de enfermagem. Enferm Foco 2018;9(3):76-80. doi: https://doi.org/10.21675/2357-707X.2018.v9.n3.1496

13. Almeida PF, Medina MG, Fausto MCR, Giovanella L, Bousquat A, Mendonça MHM. Coordenação do cuidado e Atenção Primária à Saúde no Sistema Único de Saúde. Saúde Debate. 2018;42(spe1):244-60. doi: https://doi. org/10.1590/0103-11042018s116

14. Santos MA, Scatena L, Dias MGRO, Pillon SC, Miasso Al, Souza J, et al. Grupo operativo com professores do ensino fundamental: integrando o pensar, o sentir e 0 agir. Rev SPAGESP. 2016;17(1):39-50.

15. Panzera CST. Rede de urgência e emergência no grande oeste de Santa Catarina e a educação [dissertação] Porto Alegre (RS): Universidade Federal do Rio Grande do Sul; 2017 [cited 2019 Apr 10]. Available from: http://hdl.handle. net/10183/159633

16. Ribeiro CT, Nascimento ZA. 0 encontro entre educação, saúde e psicanálise na tecitura de uma rede de cuidado às pessoas que usam drogas. Rev Latinoam Psicopatol Fundam. 2018;21(3):660-4. doi: https://doi.org/10.1590/14154714.2018v21n3p660.13

17. Pessoa BHS, Gouveia EAH, Correia IB. Funcionamento 24 horas para Unidades de Saúde da Família: uma solução para ampliação de acesso? um ensaio sobre as "upinhas" do Recife. Rev Bras Med Fam Comunidade. 2017;12(39). doi: https:// doi.org/10.5712/rbmfc12(39) 1529

18. Hirdes A. Matrix Support in mental health: the perspective of the experts on the work process. Saúde Debate. 2018;42(118):656-68. doi: https://doi. org/10.1590/0103-1104201811809

19. Farias GB, Fajardo AP. A interconsulta em serviços de Atenção Primária à Saúde. Rev Eletrôn Gestão Saúde. 2015 [cited 2019 Mar 17];6(Supl-3):2075-93. Available from: http://periodicos.unb.br/index.php/rgs/article/view/3076

20. Castro CP, Campos GWS. Apoio Matricial como articulador das relaçōes interprofissionais entre serviços especializados e atenção primária à saúde. Physis. 2016;26(2):455-81. doi: https://doi.org/10.1590/5010373312016000200007

\section{Acknowledgments:}

This paper was carried out with support from the Higher Education Personnel Improvement Coordination - Brazil (CAPES) - Financing Code 001.

\section{Associate editors:}

Marta Georgina Oliveira de Goes

Cecília Helena Glanzner

Received: 05.10.2019

Approved: 09.16.2019

\section{Editor-in-chief:}

Maria da Graça Oliveira Crossetti 